Article

\title{
Lactational Transfer of Long-Chain Perfluorinated Carboxylic Acids in Mice: A Method to Directly Collect Milk and Evaluate Chemical Transferability
}

\author{
Yukiko Fujii ${ }^{1,2, * \mathbb{D}}$, Kouji H. Harada ${ }^{1} \mathbb{D}$, Hatasu Kobayashi ${ }^{1,3}$, Koichi Haraguchi ${ }^{2}$ and \\ Akio Koizumi ${ }^{1}$ \\ 1 Department of Health and Environmental Sciences, Kyoto University Graduate School of Medicine, \\ Kyoto 606-8501, Japan; kharada-hes@umin.ac.jp (K.H.H.); hatasuk@doc.medic.mie-u.ac.jp (H.K.); \\ akiokoizumi52@gmail.com (A.K.) \\ 2 Department of Pharmaceutical Sciences, Daiichi University of Pharmacy, Fukuoka 815-8511, Japan; \\ k-haraguti@daiichi-cps.ac.jp \\ 3 Department of Environmental and Molecular Medicine, Mie University Graduate School of Medicine, \\ Tsu, Mie 514-8507, Japan \\ * Correspondence: yu-fujii@umin.ac.jp
}

Received: 15 February 2020; Accepted: 10 March 2020; Published: 1 April 2020

\begin{abstract}
Perfluoroalkyl carboxylic acids (PFCAs), such as perfluorooctanoic acid (PFOA, C8), are a group of industrial chemicals that are detected in the serum of people throughout the world. Long-chain PFCAs (C9 to C13) have high lipophilicity, therefore they may have a high transfer rate to breast milk. This study investigated the lactational transfer of PFCAs with carbon chain lengths of 8 to 13 in mice. Lactating dams were given a single intravenous administration of PFCAs (C8 to C13) during the postnatal period (8-13 days after delivery). Milk was collected from the dam $24 \mathrm{~h}$ after administration using a milking device built in-house. Plasma was obtained from the dam at the same time as milk collection. The observed milk/plasma $(\mathrm{M} / \mathrm{P})$ concentration ratios were 0.32 for $\mathrm{C} 8$, 0.30 for $\mathrm{C} 9,0.17$ for $\mathrm{C} 10,0.21$ for $\mathrm{C} 11,0.32$ for $\mathrm{C} 12$, and 0.49 for $\mathrm{C} 13$. These results indicate that the $\mathrm{M} / \mathrm{P}$ concentration ratio is not related to the lipophilicity of PFCAs. However, estimated relative daily intake, an indicator of how much PFCA is transferred from dams to pups per body weight, increased with chain length: 4.16 for $\mathrm{C} 8,8.98$ for C9, 9.35 for C10, 9.51 for C11, 10.20 for C12, and 10.49 for C13, which may be related to the lower clearance of long-chain PFCAs. These results indicate the importance of future risk assessment of long-chain PFCAs.
\end{abstract}

Keywords: perfluoroalkyl carboxylic acids; lactation; neonatal exposure; intake estimation

\section{Introduction}

The World Health Organization and academic communities, such as the American Academy of Pediatrics, recommend exclusive breastfeeding for an infant's first six months [1,2]. Breastfeeding is a standard for infant nutrition, and lowers the risk of many conditions, including otitis media, respiratory tract infections, asthma, obesity, and leukemia [3-6]. Given the medical advantages of breastfeeding, infant nutrition should be considered a public health issue [2]. However, breastfeeding is also considered a significant exposure route in infants for environmental pollutants [7].

The transfer of chemicals from blood to breastmilk is an important property with regard to breastmilk safety. Chemicals with high lipophilicity are more easily dissolved in fat and transferred into breast milk, because breastmilk is lipid-rich [8]. The milk/plasma (M/P) concentration ratio for a chemical is used as an indicator of its breastmilk transferability [9]. Although the M/P concentration 
ratio can be partially predicted by physicochemical properties [9], in vivo evaluation is essential because some chemicals have unexpected kinetics.

Perfluoroalkyl carboxylic acids (PFCAs), such as perfluorooctanoic acid (PFOA, C8), have been used as surface tension depressants and additives. PFCAs are present in the environment and have been detected in human serum. Over time, the levels of PFCAs with carbon chain lengths longer than eight $(>C 8)$ have increased in the serum of humans from East Asia and Sweden [10-13]. Perfluorinated compounds may have immunotoxic effects in children [14]. The immune system during the infant period is vulnerable [15,16], therefore PFCA exposure in the infant period is of particular interest, because breastmilk is a substantial dietary source of PFCAs in the infant period [17-19]. Estimated logarithm partition coefficients $\left(\log \mathrm{K}_{\mathrm{ow}}\right)$, an indicator of lipophilicity, increase with the chain length of PFCAs (6.4 for C8, 7.2 for C9, 7.9 for C10, 8.6 for C11, 9.4 for C12, and 10 for C13), as calculated in SciFinder via the advanced chemistry development software V11.02. Long-chain PFCAs (C9 to C13) have higher lipophilicity than C8, and therefore their transfer rate to breastmilk is expected to be higher. However, the secretion ratio of long-chain PFCAs (C9 to C13) has not been fully investigated, despite its toxicological importance.

Previously, we investigated the pharmacokinetics and mass balance of injected PFCAs in male and nonpregnant female mice [20]. The toxicokinetics were significantly different among PFCAs, indicating that lactational transfer could also depend on PFCA chain length. The aim of the present study is to assess the lactational transfer of long-chain PFCAs in an animal model. For this purpose, we conduct a kinetics study of M/P concentration ratios for PFCAs (C8 to C13) in mice. PFCA concentrations in plasma and milk of dams in the postnatal period are evaluated $24 \mathrm{~h}$ after intravenous (IV) PFCA administration.

\section{Materials and Methods}

\subsection{Materials}

PFOA (C8), perfluorononanoic acid (PFNA, C9), perfluorodecanoic acid (PFDA, C10), perfluoroun decanoic acid (PFUnDA, C11), perfluorododecanoic acid (PFDoDA, C12), tetrabutylammonium hydrogen sulfate, and $11 \mathrm{H}$-perfluoroundecanoic acid were purchased from FUJIFILM Wako Pure Chemical Corporation (Osaka, Japan). Perfluorotridecanoic acid (PFTrDA, C13) was obtained from Sigma-Aldrich (St. Louis, MO, USA). High-performance liquid chromatography (HPLC) grade methanol and methyl tert-butyl ether (MTBE) were obtained from Kanto Chemicals Co. (Tokyo, Japan). A mixture of mass labeled PFCA extraction standards, ${ }^{13} \mathrm{C}_{4}$-labeled PFOA, ${ }^{13} \mathrm{C}_{5}$-labeled PFNA, ${ }^{13} \mathrm{C}_{2}$-labeled PFDA, ${ }^{13} \mathrm{C}_{2}$-labeled PFUnDA, and ${ }^{13} \mathrm{C}_{2}$-labeled PFDoDA were obtained from Wellington Laboratories Inc. (Guelph, Canada). Benzyl bromide was obtained from the Tokyo Chemical Industry Co. (Tokyo, Japan). All other chemicals used were of the highest purity commercially available.

\subsection{Animal Handling Procedures}

All experimental procedures were approved by the Kyoto University Animal Research Committee (approved No. MedKyo11067) on 30 March 2011. Female FVB/NJcl mice in the postnatal period were used. FVB/NJcl mice were purchased from CLEA Japan, Inc. (Tokyo, Japan) and housed in the Institute of Laboratory Animals, Kyoto University. A standard commercial lab chow diet (F-2, $3.73 \mathrm{kcal} / \mathrm{g}$, Funahashi Farm Corp., Chiba, Japan) was used. All animals were maintained at an ambient temperature of $24 \pm 2{ }^{\circ} \mathrm{C}$ and $50 \pm 10 \%$ humidity with a 12-h light/dark cycle (lights on at 7:00 a.m.). Mice were provided with free access to tap water and food. Each PFCA was administered by IV injection into the tail vein. PFCAs were dissolved in ethanol and then prepared with saline ( $5 \%$ ethanol saline).

On postnatal day (PND) 8 to 13 , dams $(n=12)$ were given a single administration of PFCAs through the tail vein $(3.13 \mu \mathrm{mol} / \mathrm{kg}$ for each PFCA, injection volume $10 \mathrm{~mL} / \mathrm{kg})$. All litters were removed from their dams just before PFCA administration. To observe the PFCA concentrations in dams, milk and blood samples were collected by the following procedure. The dams were anaesthetized with sevoflurane $24 \mathrm{~h}$ after administration of PFCAs. Milk was then collected from all dams by aspirating with pulsations (described in Section 2.3). To facilitate milking, a subcutaneous injection of $4.0 \mathrm{U} / \mathrm{kg}$ 
oxytocin was given a few minutes before milking [21]. After aspiration of milk, dams were then placed under sevoflurane anesthesia and euthanized by cervical dislocation. A sample of whole blood was collected and centrifuged ( $370 \mathrm{~g}$ ) to isolate plasma. All milk and plasma samples were stored at $-20^{\circ} \mathrm{C}$ until analyzed.

\subsection{Milking Device}

Milk was collected using an in-house milking device, with modification from the previously described methods for rats [22,23]. A schematic circuit diagram and an overall photograph of the device are shown in Figure 1.
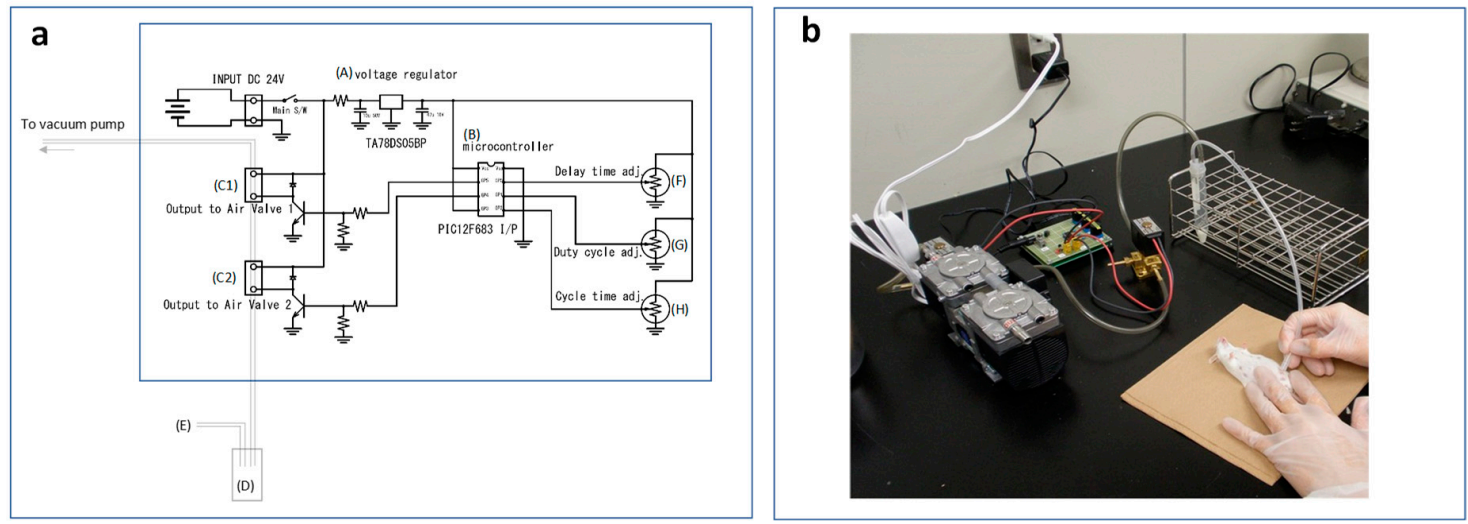

Figure 1. Mouse milking device. (a). Schematic circuit diagram of milking device. Voltage regulator (A), a microcontroller (B), two solenoid valves (C1 and C2), a milk-receiving tube (D), a teat cup (E), and three variable resistors (F, G, H). (b) Mouse being milked using the milking device.

The milking device consisted of a voltage regulator (TA78DS05BP, TOSHIBA Electronic Devices \& Storage Corporation, Tokyo, Japan) (A), a microcontroller (PIC12F683 I/P, Microchip Technology, AZ, USA) (B), two solenoid valves (SMC Corporation, Tokyo, Japan) (C1 and C2), a milk-receiving tube (15 mL centrifuge tube) (D), and a teat cup (Little Leonardo Co., Tokyo, Japan) (E). Vacuum power (6.65 kPa or higher) was obtained from a diaphragm-type dry vacuum pump from ULVAC KIKO, Inc. (Miyazaki, Japan).

To use the milking device, the vacuum pump was started, and three variable resistors $(\mathrm{F}, \mathrm{G}$, and $\mathrm{H})$ connected to the two control solenoid valves (C1 and $\mathrm{C} 2$ ) were adjusted to give the optimum pulsation frequency on the teat cup. More detailed information is shown in the Supplementary Materials. Once these were set, it was not necessary to adjust them again. We followed the milking conditions as described by Cox and Mueller (1937), with around 40 pulsations per min. Enough milk (0.5 to $1 \mathrm{~mL})$ was collected from all dams for analysis.

\subsection{Determination of PFCAs in Plasma and Milk}

Determination of PFCAs was performed by gas chromatography-mass spectrometry (GC-MS, Agilent 6890GC/5973inertMSD) following a previously described method [20,24,25], with slight modification. Briefly, approximately $100 \mu \mathrm{L}$ milk or $10 \mu \mathrm{L}$ plasma were used for liquid-liquid extraction. A sample and an internal standard mixture $\left(1 \mathrm{ng}\right.$ each of ${ }^{13} \mathrm{C}_{4}$-labeled PFOA, ${ }^{13} \mathrm{C}_{5}$-labeled PFNA, ${ }^{13} \mathrm{C}_{2}$-labeled PFDA, ${ }^{13} \mathrm{C}_{2}$-labeled PFUnDA, and ${ }^{13} \mathrm{C}_{2}$-labeled PFDoDA in methanol) were added to the tube. Next, $0.5 \mathrm{~mL}$ of $0.5 \mathrm{~mol} \mathrm{~L}{ }^{-1}$ tetrabutylammonium hydrogen sulfate $/ 0.25 \mathrm{~mol} \mathrm{~L}^{-1}$ sodium carbonate buffer ( $\mathrm{pH} 10), 0.5 \mathrm{~mL}$ methanol, and $2 \mathrm{~mL} \mathrm{MTBE}$ were added, and the tube was vortexed for $2 \mathrm{~min}$. The samples were then centrifuged at $9840 \mathrm{~g}$ for $5 \mathrm{~min}$ and the organic layer was collected. This step was repeated and the organic layers were combined in a clean test tube and then evaporated to dryness under a nitrogen stream. The residue was re-dissolved in $100 \mu \mathrm{L}$ of a solution of $0.1 \mathrm{~mol}$ $\mathrm{L}^{-1}$ benzyl bromide in acetone, which contained $10 \mathrm{ng} 11 \mathrm{H}$-perfluoroundecanoic acid as an injection 
standard. The solution was then heated at $60{ }^{\circ} \mathrm{C}$ for $1 \mathrm{~h}$ to derivatize the PFCAs to benzyl esters. The derivatized PFCAs were analyzed by GC-MS with electron capture negative ionization in the selected ion monitoring mode [24]. The instrumental detection limit was defined as the mass of the analyte producing a peak with a signal-to-noise ratio of three. Milli-Q water was used for the procedural blank control $(n=6)$. For blank levels, the method detection limits (MDLs) were defined by the following equation: $\mathrm{MDL}=\alpha+3 \beta$, where $\alpha$ is the mean of the blank signals and $\beta$ is the standard deviation of the blank signals. The MDLs in plasma were $0.02 \mu \mathrm{mol} / \mathrm{L}$ for C $8,0.01 \mu \mathrm{mol} / \mathrm{L}$ for C9 and $\mathrm{C} 10,0.005 \mu \mathrm{mol} / \mathrm{L}$ for C11, C12 and C13. The MDLs in milk were $0.002 \mu \mathrm{mol} / \mathrm{L}$ for C8, $0.001 \mu \mathrm{mol} / \mathrm{L}$ for C9 and C10, $0.0005 \mu \mathrm{mol} / \mathrm{L}$ for C11, C12 and C13. Thus, the blank levels did not affect the analysis of samples. PFCA levels in serum and milk samples from control mice were less than MDLs.

\subsection{M/P Concentration Ratio, Estimated Daily Intake (EDI) of Pups, EDI of Dams, and Estimated Relative Daily Intake (ERDI) between Dams and Pups}

\subsection{1. $\mathrm{M} / \mathrm{P}$ Concentration Ratio}

The M/P concentration ratio is used as a standard indicator of breastmilk transferability of chemicals [9]. Our previous study showed that PFCAs (C8 to C13) in plasma increase in the 6-12 $\mathrm{h}$ after administration and become stable within $24 \mathrm{~h}$ [20]. Based on this finding, we collected plasma and milk at $24 \mathrm{~h}$ after administration. The $\mathrm{M} / \mathrm{P}$ concentration ratio was obtained using the following Equation (1):

$$
\begin{aligned}
& \mathrm{M} / \mathrm{P} \text { concentration ratio }= \\
& \text { Concentration in milk at } 24 \mathrm{~h} \text { after administration }(\mu \mathrm{mol} / \mathrm{L})
\end{aligned}
$$

\subsubsection{Estimated Daily Intake (EDI) of Pups}

The EDI of pups ( $\mu \mathrm{mol} / \mathrm{kg} / \mathrm{day})$ was obtained using the PFCA concentrations in milk, daily milk consumption, and the calculated bodyweight of pups [26]. All factors used for estimation are summarized in Table 1. Since our study collected milk from dams between PND 8 and 13, we set PND 10 as the evaluation day. The bodyweights of FVB pups were reported as $4.7 \mathrm{~g}$ at PND 8 , then $6.8 \mathrm{~g}$ at PND 13 [27]. Thus, we assumed a body weight gain of $2.1 \mathrm{~g}$ between PND 8 and PND 13 was proportional for the period $(0.42 \mathrm{~g} /$ day $)$. Estimated milk consumption was obtained by doubling the average daily body weight gain ( $0.84 \mathrm{~g}$ milk per day) because $50 \%$ of consumed milk weight is assumed to correspond to daily body weight gain [26,28]. The specific weight for breastmilk is 1.017 [29], so daily pup intake of milk was set at $0.85 \times 10^{-4} \mathrm{~L} /$ day. Body weight for pups at PND 10 was set as $5.5 \mathrm{~g}$ based on a previous study [27]. The EDI of pups was calculated using the following Equation (2):

$$
\begin{aligned}
& \text { EDI of pups }(\mu \mathrm{mol} / \mathrm{kg} / \text { day })= \\
& \frac{\text { PFCA concentration in milk }(\mu \mathrm{mol} / \mathrm{L}) \times \text { estimated milk consumption per day }(\mathrm{L} / \text { day })}{\text { Pup bodyweight }(\mathrm{kg})}
\end{aligned}
$$

\subsubsection{EDI of Dams}

The EDI of dams ( $\mu \mathrm{mol} / \mathrm{kg} /$ day) was obtained using the plasma PFCA concentrations in this study and the PFCA clearances previously reported by Fujii et al., 2015 [20]. We administered PFCAs to dams in a single dose; therefore, the EDI of dams was converted from the obtained plasma PFCA concentrations [30]. It was assumed that plasma PFCA concentrations $24 \mathrm{~h}$ after a single administration reached steady-state and that toxicokinetic parameters were similar between non-lactating and lactating mice. All factors used for the calculation are summarized in Table 1. The EDI of dams was calculated by the following Equation (3): 
EDI of dams $(\mu \mathrm{mol} / \mathrm{kg} /$ day $)=$

PFCA concentration in plasma $(\mu \mathrm{mol} / \mathrm{L}) \times$ total PFCA clearances $(\mathrm{L} / \mathrm{kg} /$ day $)$.

A previous study comparing oral and IV administration showed no difference in absorbed dose and $98 \%-99 \%$ of the administered C 8 to C13 PFCAs were efficiently absorbed in the gut [20]; therefore, no adjustment was conducted.

\subsubsection{Estimated Relative Daily Intake (ERDI) between Dams and Pups}

ERDI is an indicator of how much of the dam EDI was transferred to pups via the dam's milk [31,32]. The ERDI between dams and pups was calculated using the following Equation (4):

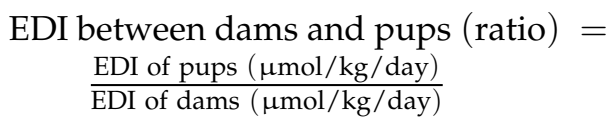

Table 1. Factors and values used to estimate doses to pups via lactation, and relative doses to pups from dams.

\begin{tabular}{|c|c|c|}
\hline Factor & Value & Reference \\
\hline (A) PFCA concentrations in milk (C8-C13) & Shown in Table $2(\mu \mathrm{mol} / \mathrm{L})$ & the present study \\
\hline (B) Body weight of FVB mice at PND 8 & $4.7 \mathrm{~g}$ & Eshraghi et al., 2016 [27] \\
\hline (C) Body weight of FVB mice at PND 13 & $6.8 \mathrm{~g}$ & Eshraghi et al., 2016 [27] \\
\hline $\begin{array}{l}\text { (D) Body weight gain between PND } 8 \text { and } \\
\text { PND } 13\end{array}$ & $2.1 \mathrm{~g}$ & (C)-(B) \\
\hline (E) Average daily body weight gain & $0.42 \mathrm{~g} /$ day & $(\mathrm{D}) / 5$ \\
\hline $\begin{array}{l}\text { (F) Estimated milk consumption weight } \\
\text { per day }\end{array}$ & $0.84 \mathrm{~g} /$ day & $\begin{array}{l}(\mathrm{E}) \times 2 \\
\text { (Grigor and Thompson, } 1987 \text { [28], } \\
\text { Goerge et al., 2010 [26]) }\end{array}$ \\
\hline $\begin{array}{l}\text { (G) Estimated milk consumption volume } \\
\text { per day }\end{array}$ & $8.5 \times 10^{-4} \mathrm{~L} /$ day & $\begin{array}{c}(\mathrm{F}) \times 1.017 \text { (Breastmilk specific } \\
\text { weight, g/L }) \times 10^{-3} \\
(\text { Suzuki et al., 2004 [29] })\end{array}$ \\
\hline (H) Body weight of pups at PND 10 & $5.5 \mathrm{~g}$ & (B) $+(\mathrm{E}) \times 2$ \\
\hline (I) EDI of pups & Shown in Table 3 ( $\mu \mathrm{mol} / \mathrm{kg} /$ day) & $\begin{array}{c}(\mathrm{A}) \times(\mathrm{G}) /(\mathrm{H}) \\
\ldots \text { Equation }(2)\end{array}$ \\
\hline $\begin{array}{l}\text { (J) PFCA concentrations in plasma } \\
\text { (C8-C13) }\end{array}$ & Shown in Table $2(\mu \mathrm{mol} / \mathrm{L})$ & the present study \\
\hline (K) Total PFCA clearances (C8-C13) & $\begin{array}{c}\text { C8; } 0.012, \text { C } 9 ; 0.005, \mathrm{C} 10 ; 0.003 \\
\text { C11; } 0.003, \text { C12; } 0.005, \text { C13; } 0.007 \\
\text { (L/kg/day) }\end{array}$ & Fujii et al., 2015 [20] \\
\hline (L) EDI of dams & Shown in Table 3 ( $\mu \mathrm{mol} / \mathrm{kg} /$ day) & $\begin{array}{c}\quad(\mathrm{J}) \times(\mathrm{K}) \\
\ldots \text { Equation }(3)\end{array}$ \\
\hline (M) ERDI between dams and pups & Shown in Table 3 (ratio) & $\begin{array}{c}(\mathrm{I}) /(\mathrm{L}) \\
\ldots \text { Equation }(4)\end{array}$ \\
\hline
\end{tabular}

PFCA: Perfluoroalkyl carboxylic acids. PND: postnatal day. EDI: Estimated daily intake. ERDI: Estimated relative daily intake. Bold factors are shown in Table 3.

\subsection{Statistical Analysis}

The data are presented as the mean and standard deviation (SD). All statistical analysis was conducted using JMP 13 (SAS Institute Inc., Cary, NC, USA). Statistical significance of the difference in PFCA levels between milk and plasma was assessed using the paired $t$-test (two-sided) with $p<0.05$ as the acceptance criterion. Statistical significance of the differences in PFCA levels among the different 
chain lengths (C8 to C13) was assessed using one-way analysis of variance with $p<0.05$ as the acceptance criterion.

\section{Results and Discussion}

\subsection{M/P Concentration Ratio of PFCAs}

PFCA concentrations in dam plasma and milk at $24 \mathrm{~h}$ after PFCA administration are summarized in Table 2. The highest concentrations in plasma were for $\mathrm{C} 8(13.78 \mu \mathrm{mol} / \mathrm{L})$, followed by $\mathrm{C} 9(11.00 \mu \mathrm{mol} / \mathrm{L})$, $\mathrm{C} 10(3.43 \mu \mathrm{mol} / \mathrm{L}), \mathrm{C} 11(2.42 \mu \mathrm{mol} / \mathrm{L}), \mathrm{C} 12(1.10 \mu \mathrm{mol} / \mathrm{L})$, and C13 $(0.63 \mu \mathrm{mol} / \mathrm{L})$. This trend was consistent with observations of non-lactating female mice (Fujii et al. 2015). Milk contained measurable levels of PFCAs. The highest concentration in milk was for C8 $(4.38 \mu \mathrm{mol} / \mathrm{L})$, and levels decreased with increasing chain length (C9: $3.30 \mu \mathrm{mol} / \mathrm{L}, \mathrm{C} 10: 0.57 \mu \mathrm{mol} / \mathrm{L}, \mathrm{C} 11: 0.46 \mu \mathrm{mol} / \mathrm{L}, \mathrm{C} 12: 0.29 \mu \mathrm{mol} / \mathrm{L}$, and C13: $0.23 \mu \mathrm{mol} / \mathrm{L}$ ). The concentrations of PFCA in dam milk were significantly lower than those observed in plasma ( $p<0.05$ by paired $t$-test). The observed M/P concentration ratio was 0.32 for $\mathrm{C} 8,0.30$ for $\mathrm{C} 9,0.17$ for $\mathrm{C} 10,0.21$ for $\mathrm{C} 11,0.32$ for $\mathrm{C} 12$, and 0.49 for $\mathrm{C} 13$. There was a statistically significant difference in M/P ratios among PFCAs $(p<0.05$, ANOVA). The C8 M/P concentration ratio in the present study was similar to that reported in a previous study (milk/serum concentration ratio was 0.31 , when $0.1 \mathrm{mg} / \mathrm{kg} \mathrm{C8}$ was administrated on PND 4) [33], supporting the validity of this study. $\mathrm{C} 8$ and $\mathrm{C} 9$ had comparable $\mathrm{M} / \mathrm{P}$ ratios to $\mathrm{C} 12$ and $\mathrm{C} 13$. Considering that longer chain PFCAs have higher lipophilicity, this result revealed that the M/P concentration ratios of PFCAs are not simply related to their lipophilicity. Chemicals with an $\mathrm{M} / \mathrm{P}$ concentration ratio less than 1.0 are classified as low risk [34]. According to this drug safety indicator, all PFCAs were classified as low risk.

The biochemical mechanisms that transfer PFCAs into milk are not well understood; however, the transfer of chemicals to breast milk is affected by physicochemical properties, not only lipophilicity but also protein binding affinity [9]. Chemicals with high plasma-protein binding rates have low transferability to breast milk [8]. PFCAs have a high affinity for protein binding in serum [35,36], which may strongly affect the $\mathrm{M} / \mathrm{P}$ concentration ratio of them regardless of $\log \mathrm{P}$.

Table 2. Perfluoroalkyl carboxylic acids (PFCA) concentrations in milk and plasma in lactating mice, $24 \mathrm{~h}$ after a single IV administration $(3.13 \mu \mathrm{mol} / \mathrm{kg})$.

\begin{tabular}{|c|c|c|c|c|c|c|c|}
\hline & & $\begin{array}{l}\text { PFOA } \\
\text { (C8) }\end{array}$ & $\begin{array}{l}\text { PFNA } \\
\text { (C9) }\end{array}$ & $\begin{array}{l}\text { PFDA } \\
\text { (C10) }\end{array}$ & $\begin{array}{l}\text { PFUnDA } \\
\text { (C11) }\end{array}$ & $\begin{array}{l}\text { PFDoDA } \\
\text { (C12) }\end{array}$ & $\begin{array}{c}\text { PFTrDA } \\
\text { (C13) }\end{array}$ \\
\hline Milk & $\mu \mathrm{mol} / \mathrm{L}$ & $4.38(1.15)^{*}$ & $3.30(2.15)^{*}$ & $0.57(0.20)^{*}$ & $0.46(0.19) *$ & $0.29(0.10) *$ & $0.23(0.07)$ * \\
\hline Plasma & $\mu \mathrm{mol} / \mathrm{L}$ & $13.78(2.21)$ & $11.00(5.46)$ & $3.43(0.75)$ & $2.42(1.63)$ & $1.10(0.53)$ & $0.63(0.39)$ \\
\hline Milk/Plasma ${ }^{\text {a }}$ & ratio & $0.32(0.07)$ & $0.30(0.10)$ & $0.17(0.07)$ & $0.21(0.07)$ & $0.32(0.15)$ & $0.49(0.27)$ \\
\hline
\end{tabular}

\subsection{Estimated Lactational Transfer from Dams to Pups}

The EDI of pups and the ERDI between dams and pups were calculated to evaluate the toxicokinetics of PFCAs (Table 3). The ERDI was calculated from the EDI of pups, which was converted from the PFCA concentration in the dam's milk, and the EDI of dams, which was converted from the PFCA concentration in the dam's plasma (see Section 2.5).

\subsubsection{EDI of Pups}

The highest amount ( $\mu \mathrm{mol} / \mathrm{kg} /$ day) was observed for C8 (0.68), followed by C9 (0.51), C10 (0.09), C11 (0.07), C12 (0.05), and C13 (0.04) (Table 3). This study showed that the EDI of pups decreased with increasing chain length. The volume distribution of long-chain PFCAs (C10 to C13) was higher than that of $\mathrm{C} 8$ to $\mathrm{C} 9$ [20], indicating that long-chain PFCAs (C10 to C13) are more highly distributed in 
tissue than in plasma. Thus, concentrations of $\mathrm{C} 10$ to $\mathrm{C} 13$ in breastmilk are lower than those of $\mathrm{C} 8$ to $\mathrm{C} 9$, although the $\mathrm{M} / \mathrm{P}$ concentration ratio is similar among $\mathrm{C} 8$ to $\mathrm{C} 13$.

\subsubsection{EDI of Dams and ERDI between Dams and Pups}

The EDI of dams ( $\mu \mathrm{mol} / \mathrm{kg} /$ day) was 0.163 for C8, 0.056 for C $9,0.010$ for $\mathrm{C} 10,0.008$ for $\mathrm{C} 11,0.005$ for $\mathrm{C} 12$, and 0.005 for $\mathrm{C} 13$ (Table 3). The ERDI between dams and pups (EDI of pups/EDI of dams) was 4.16 for $\mathrm{C} 8,8.98$ for $\mathrm{C} 9,9.35$ for $\mathrm{C} 10,9.51$ for C11, 10.20 for $\mathrm{C} 12$, and 10.49 for C13 (Table 3). Hale (2010) categorized drugs with a ERDI of less than 0.1 and rated them as generally safe [31]. According to this drug safety indicator, all PFCAs were classified as high risk. The ERDIs of PFCAs increased with increasing chain length, which may be mostly related to the lower clearance of long-chain PFCAs [20]. This result indicates the importance of future risk assessment for long-chain PFCAs.

Table 3. Estimated lactational transfer from dams to pups.

\begin{tabular}{|c|c|c|c|c|c|c|c|}
\hline & & $\begin{array}{c}\text { PFOA } \\
\text { (C8) }\end{array}$ & $\begin{array}{l}\text { PFNA } \\
\text { (C9) }\end{array}$ & $\begin{array}{l}\text { PFDA } \\
\text { (C10) }\end{array}$ & $\begin{array}{l}\text { PFUnDA } \\
\text { (C11) }\end{array}$ & $\begin{array}{l}\text { PFDoDA } \\
\text { (C12) }\end{array}$ & $\begin{array}{c}\text { PFTrDA } \\
\text { (C13) }\end{array}$ \\
\hline EDI of pups ${ }^{a}$ & $\mu \mathrm{mol} / \mathrm{kg} /$ day & $\begin{array}{c}0.68 \\
(0.18)\end{array}$ & $\begin{array}{c}0.51 \\
(0.33)\end{array}$ & $\begin{array}{c}0.09 \\
(0.03)\end{array}$ & $\begin{array}{c}0.07 \\
(0.03)\end{array}$ & $\begin{array}{c}0.05 \\
(0.02)\end{array}$ & $\begin{array}{c}0.04 \\
(0.01)\end{array}$ \\
\hline EDI of dams ${ }^{b}$ & $\mu \mathrm{mol} / \mathrm{kg} /$ day & $\begin{array}{c}0.163 \\
(0.025)\end{array}$ & $\begin{array}{c}0.056 \\
(0.027)\end{array}$ & $\begin{array}{c}0.010 \\
(0.002)\end{array}$ & $\begin{array}{c}0.008 \\
(0.005)\end{array}$ & $\begin{array}{c}0.005 \\
(0.002)\end{array}$ & $\begin{array}{c}0.005 \\
(0.003)\end{array}$ \\
\hline $\begin{array}{l}\text { ERDI between } \\
\text { dams and pups }\end{array}$ & ratio & $\begin{array}{l}4.16 \\
(0.87)\end{array}$ & $\begin{array}{c}8.98 \\
(3.15)\end{array}$ & $\begin{array}{c}9.35 \\
(3.84)\end{array}$ & $\begin{array}{c}9.51 \\
(2.96)\end{array}$ & $\begin{array}{l}10.20 \\
(4.95)\end{array}$ & $\begin{array}{l}10.49 \\
(5.87)\end{array}$ \\
\hline
\end{tabular}

The data are presented as the mean (SD). EDI: Estimated daily intake. ERDI: Estimated relative daily intake.

${ }^{a}$ See Equation (2) in Section 2.5.2. ${ }^{b}$ See Equation (3) in Section 2.5.3. ${ }^{c}$ See Equation (4) in Section 2.5.4.

\subsection{Limitations of this Study}

There are several limitations of this study that should be noted in its relevance to assessment of human exposure. Human mammary glands express organic anion transporters [37] and PFOA and other PFCAs are substrates for these transporters [38-40]. There are some species differences in substance selectivity between mouse and human organic anion transporters [41]. These species differences should be investigated in future studies. Second, during the lactation period, the M/P concentration ratio and ERDI may vary between colostrum and mature milk.

\section{Conclusions}

This study reported the secretion profile (plasma to milk) of PFCAs with six different carbon chain lengths ( $\mathrm{C} 8$ to $\mathrm{C} 13)$ in mice. The observed M/P concentration ratios were lowest for $\mathrm{C} 10(0.17)$ and highest for $\mathrm{C} 13$ (0.49). This indicates that the secretion ratio is not directly related to the estimated $\log \mathrm{K}_{\mathrm{ow}}$ of PFCAs. However, all PFCAs had high ERDI between dams and pups $(4<)$, indicating the importance of future risk assessment of long-chain PFCAs. The animal experimentation method used in this study can be used to investigate environmental pollutants in infants.

Supplementary Materials: The following are available online at http://www.mdpi.com/2305-6304/8/2/23/s1, Figure. S1. Movement of two solenoid valves (C1 and C2) in the milking device.

Author Contributions: Conceptualization, Y.F. and A.K.; Investigation, Y.F., K.H.H., and H.K.; Funding acquisition, Y.F.; Resources, A.K. and K.H.; Writing—original draft, Y.F.; Writing—review and editing, H.K., K.H.H., K.H., and A.K. All authors have read and agreed to the published version of the manuscript.

Funding: This work was supported by a Grant-in-Aid from the Japan Society for the Promotion of Science (Y.F.: 26881008 and 16K00565) and The Japan Health Foundation.

Acknowledgments: We thank Shinichiro Fujii for support in designing the in-house milking device.

Conflicts of Interest: The authors declare no conflict of interest. 


\section{References}

1. WHO. The Optimal Duration of Exclusive Breastfeeding. 2001. Vol. WHO/NHD/01.09, WHO/FCH/CAH/01.24. Available online: https://www.who.int/nutrition/publications/infantfeeding/WHO_NHD_01.09/en/ (accessed on 24 March 2020).

2. Eldelman, A.I.; Schandler, R.J. American Academy of Pediatrics policy statement: Breastfeeding and the Use of Human Milk. Pediatrics 2012, 129, e827-e841. [CrossRef]

3. Ip, S.; Chung, M.; Raman, G.; Chew, P.; Magula, N.; DeVine, D.; Trikalinos, T.; Lau, J. Breastfeeding and maternal and infant health outcomes in developed countries. Evid. Rep./Technol. Assess. 2007, 153, 1-186.

4. Chantry, C.J.; Howard, C.R.; Auinger, P. Full breastfeeding duration and associated decrease in respiratory tract infection in US children. Pediatrics 2006, 117, 425-432. [CrossRef]

5. Kwan, M.L.; Buffler, P.A.; Abrams, B.; Kiley, V.A. Breastfeeding and the risk of childhood leukemia: A meta-analysis. Public Health Rep. 2004, 119, 521-535. [CrossRef]

6. Rudant, J.; Orsi, L.; Menegaux, F.; Petit, A.; Baruchel, A.; Bertrand, Y.; Lambilliotte, A.; Robert, A.; Michel, G.; Margueritte, G.; et al. Childhood acute leukemia, early common infections, and allergy: The ESCALE Study. Am. J. Epidemiol. 2010, 172, 1015-1027. [CrossRef]

7. Boue, G.; Cummins, E.; Guillou, S.; Antignac, J.P.; Le Bizec, B.; Membre, J.M. Public health risks and benefits associated with breast milk and infant formula consumption. Crit. Rev. Food Sci. Nutr. 2018, 58, 126-145. [CrossRef] [PubMed]

8. Hayashi, M. Medications in pregnancy and lactation: Assessment of risks to fetus and infants. Organ Biol. 2011, 18, 279-286. [CrossRef]

9. Larsen, L.A.; Ito, S.; Koren, G. Prediction of milk/plasma concentration ratio of drugs. Ann Pharm. 2003, 37, 1299-1306. [CrossRef]

10. Glynn, A.; Berger, U.; Bignert, A.; Ullah, S.; Aune, M.; Lignell, S.; Darnerud, P.O. Perfluorinated Alkyl Acids in Blood Serum from Primiparous Women in Sweden: Serial Sampling during Pregnancy and Nursing, And Temporal Trends 1996-2010. Environ. Sci. Technol. 2012, 46, 9071-9079. [CrossRef] [PubMed]

11. Harada, K.H.; Hitomi, T.; Niisoe, T.; Takanaka, K.; Kamiyama, S.; Watanabe, T.; Moon, C.S.; Yang, H.R.; Hung, N.N.; Koizumi, A.; et al. Odd-numbered perfluorocarboxylates predominate over perfluorooctanoic acid in serum samples from Japan, Korea and Vietnam. Environ. Int. 2011, 37, 1183-1189. [CrossRef]

12. Fujii, Y.; Harada, K.H.; Haraguchi, K.; Koizumi, A. Long-term trends in dietary intake of perfluoroalkyl carboxylic acids in relation to their serum concentration in two regions in Japan from 1979 to 2011. Chemosphere 2017, 176, 165-174. [CrossRef] [PubMed]

13. Okada, E.; Kashino, I.; Matsuura, H.; Sasaki, S.; Miyashita, C.; Yamamoto, J.; Ikeno, T.; Ito, Y.M.; Matsumura, T.; Tamakoshi, A.; et al. Temporal trends of perfluoroalkyl acids in plasma samples of pregnant women in Hokkaido, Japan, 2003-2011. Environ. Int 2013, 60, 89-96. [CrossRef] [PubMed]

14. Grandjean, P.; Andersen, E.W.; Budtz-Jorgensen, E.; Nielsen, F.; Molbak, K.; Weihe, P.; Heilmann, C. Serum vaccine antibody concentrations in children exposed to perfluorinated compounds. Jama 2012, 307, 391-397. [CrossRef] [PubMed]

15. Barouki, R.; Gluckman, P.D.; Grandjean, P.; Hanson, M.; Heindel, J.J. Developmental origins of non-communicable disease: Implications for research and public health. Environ. Health Glob. Access Sci. Source 2012, 11, 42. [CrossRef]

16. Bruckner, J.V. Differences in sensitivity of children and adults to chemical toxicity: The NAS panel report. Regul. Toxicol. Pharmacol. Rtp. 2000, 31, 280-285. [CrossRef]

17. Mogensen, U.B.; Grandjean, P.; Nielsen, F.; Weihe, P.; Budtz-Jørgensen, E. Breastfeeding as an Exposure Pathway for Perfluorinated Alkylates. Environ. Sci. Technol. 2015, 49, 10466-10473. [CrossRef]

18. Kärrman, A.; Ericson, I.; Van Bavel, B.; Darnerud, P.O.; Aune, M.; Glynn, A.; Lignell, S.; Lindström, G. Exposure of perfluorinated chemicals through lactation: Levels of matched human milk and serum and a temporal trend, 1996-2004, in Sweden. Environ. Health Perspect. 2007, 115, 226-230. [CrossRef]

19. Fujii, Y.; Yan, J.X.; Harada, K.H.; Hitomi, T.; Yang, H.; Wang, P.Y.; Koizumi, A. Levels and profiles of long-chain perfluorinated carboxylic acids in human breast milk and infant formulas in East Asia. Chemosphere 2012, 86, 315-321. [CrossRef]

20. Fujii, Y.; Niisoe, T.; Harada, K.H.; Uemoto, S.; Ogura, Y.; Takenaka, K.; Koizumi, A. Toxicokinetics of perfluoroalkyl carboxylic acids with different carbon chain lengths in mice and humans. J. Occup. Health 2015, 57, 1-12. [CrossRef] 
21. Oskarsson, A.; Möller, N. A method for studies on milk excretion of chemicals in mice with $2,2^{\prime}, 4,4^{\prime}, 5-$ pentabromodiphenyl ether (BDE-99) as a model. Toxicol. Lett. 2004, 151, 327-334. [CrossRef]

22. Temple, P.L.; Kon, S.A. A simple apparatus for milking small laboratory animals. Biochem. J. 1937, 31, 2197-2198. [CrossRef]

23. Cox, W.M., Jr.; Mueller, A.J. The Composition of Milk from Stock Rats and an Apparatus for Milking Small Laboratory Animals: Two Text Figures and one Plate (One Figure). J. Nutr. 1937, 13, 249-261. [CrossRef]

24. Fujii, Y.; Harada, K.H.; Koizumi, A. Analysis of perfluoroalkyl carboxylic acids in composite dietary samples by gas chromatography/mass spectrometry with electron capture negative ionization. Environ. Sci. Technol. 2012, 46, 11235-11242. [CrossRef] [PubMed]

25. Fujii, Y.; Harada, K.H.; Koizumi, A. Occurrence of perfluorinated carboxylic acids (PFCAs) in personal care products and compounding agents. Chemosphere 2013, 93, 538-544. [CrossRef] [PubMed]

26. Doerge, D.R.; Vanlandingham, M.; Twaddle, N.C.; Delclos, K.B. Lactational transfer of bisphenol A in Sprague-Dawley rats. Toxicol Lett 2010, 199, 372-376. [CrossRef]

27. Eshraghi, M.; McFall, E.; Gibeault, S.; Kothary, R. Effect of genetic background on the phenotype of the Smn2B/- mouse model of spinal muscular atrophy. Hum. Mol. Genet. 2016, 25, 4494-4506. [CrossRef]

28. Grigor, M.R.; Thompson, M.P. Diurnal regulation of milk lipid production and milk secretion in the rat: Effect of dietary protein and energy restriction. J. Nutr. 1987, 117, 748-753. [CrossRef]

29. Suzuki, K.; Sasaki, S.; Shinzawa, K.; Totani, M. Milk Intake by Breast-fed Infants before weaning. Jpn. J. Nutr. Diet. 2004, 62, 369-372. [CrossRef]

30. Rosenbaum, S.E. Basic Pharmacokinetics and Pharmacodynamics: An Integrated Textbook and Computer Simulations; John Wiley \& Sons, Inc.: New York, NY, USA, 2016; ISBN 9781119143185.

31. Hale, T.W. Hale's Medications and Mothers' Milk; Springer Publishing Company: New York, NY, USA, 2010.

32. Astrup-Jensen, A.; Bates, C.J.; Begg, E.J.; Edwards, S.; Lazarus, C.; Matheson, I.; Mountford, P.J.; Neville, M.C.; Notarianni, L.J.; Prentiss, A.; et al. Drugs and Human Lactation, 2nd ed.; Elsevier Science: Amsterdam, The Netherlands, 1996; ISBN 9780080530550.

33. Fenton, S.E.; Reiner, J.L.; Nakayama, S.F.; Delinsky, A.D.; Stanko, J.P.; Hines, E.P.; White, S.S.; Lindstrom, A.B.; Strynar, M.J.; Petropoulou, S.-S.E.; et al. Analysis of PFOA in dosed CD-1 mice. Part 2: Disposition of PFOA in tissues and fluids from pregnant and lactating mice and their pups. Reprod. Toxicol. 2009, 27, 365-372. [CrossRef]

34. Fatemi, M.H.; Ghorbanzad'e, M. Classification of drugs according to their milk/plasma concentration ratio. Eur J Med Chem 2010, 45, 5051-5055. [CrossRef]

35. Jones, P.D.; Hu, W.; De Coen, W.; Newsted, J.L.; Giesy, J.P. Binding of perfluorinated fatty acids to serum proteins. Environ. Toxicol. Chem./Setac 2003, 22, 2639-2649. [CrossRef] [PubMed]

36. Zhang, L.; Ren, X.M.; Guo, L.H. Structure-based investigation on the interaction of perfluorinated compounds with human liver fatty acid binding protein. Environ. Sci Technol 2013, 47, 11293-11301. [CrossRef] [PubMed]

37. Ito, S.; Alcorn, J. Xenobiotic transporter expression and function in the human mammary gland. Adv. Drug Deliv. Rev. 2003, 55, 653-665. [CrossRef]

38. Nakagawa, H.; Terada, T.; Harada, K.H.; Hitomi, T.; Inoue, K.; Inui, K.-I.; Koizumi, A. Human Organic Anion Transporter hOAT4 is a Transporter of Perfluorooctanoic Acid. Basic Clin. Pharmacol. Toxicol. 2009, 105, 136-138. [CrossRef] [PubMed]

39. Nakagawa, H.; Hirata, T.; Terada, T.; Jutabha, P.; Miura, D.; Harada, K.H.; Inoue, K.; Anzai, N.; Endou, H.; Inui, K.-I.; et al. Roles of Organic Anion Transporters in the Renal Excretion of Perfluorooctanoic Acid. Basic Clin. Pharmacol. Toxicol. 2008, 103, 1-8. [CrossRef] [PubMed]

40. Yang, C.H.; Glover, K.P.; Han, X. Characterization of cellular uptake of perfluorooctanoate via organic anion-transporting polypeptide 1A2, organic anion transporter 4, and urate transporter 1 for their potential roles in mediating human renal reabsorption of perfluorocarboxylates. Toxicol. Sci. Off. J. Soc. Toxicol. 2010, 117, 294-302. [CrossRef]

41. Tahara, H.; Kusuhara, H.; Endou, H.; Koepsell, H.; Imaoka, T.; Fuse, E.; Sugiyama, Y. A species difference in the transport activities of $\mathrm{H} 2$ receptor antagonists by rat and human renal organic anion and cation transporters. J. Pharmacol. Exp. Ther. 2005, 315, 337-345. [CrossRef]

(C) 2020 by the authors. Licensee MDPI, Basel, Switzerland. This article is an open access article distributed under the terms and conditions of the Creative Commons Attribution (CC BY) license (http://creativecommons.org/licenses/by/4.0/). 